\title{
A STUDY OF BARBITURATE INTOXICATION BY AN ULTRA-VIOLET SPECTROPHOTOMETRIC TECHNIQUE
}

\author{
BY
}

\author{
J. T. WRIGHT AND R. G. S. JOHNS \\ From the London Hospital, E.I
}

(RECEIVED FOR PUblication AUGUST 23, 1952)

The diagnosis of barbiturate intoxication is usually made from circumstantial evidence coupled with a characteristic, if non-specific, clinical picture. The need for a confirmatory laboratory test is often felt.

Riley, Krause, Steadman, Hunter, and Hodge (1940) have described the shortcomings of the commonly used cobalt co'our reactions. The extraction of barbiturate crystals and the determination of their melting point must remain the most satisfactory method of analysis for medico-legal work, but this technique is limited in clinical practice by the large quantities of biological material required and by the time involved in the extraction and purification processes.

During the past decade research has proceeded along a number of lines, including ultra-violet and infra-red spectroscopy, $x$-ray crystallography, and paper chromatography. Most attention has been directed to ultra-violet spectrophotometry, which is at present the most practicable procedure in view of available suitable equipment. The details of procedure and the form of the absorption curve are similar for all but the thio-barbiturates, which absorb in a different region of the spectrum, but the general shape of the absorption curve is of some, though limited, qualitative value in identifying the particular barbiturate present.

The ultra-violet absorption spectra of barbiturate compounds have of course been known for many years. In 1940 Stuckey studied the absorption of a number of derivatives in acid and alkaline solution and came to important conclusions about their characteristics from which he suggested that the technique might be applicable to the analysis of tissues containing barbiturate. At the same time Elvidge (1940) assayed barbiturate tablets by this method. Jailer and Goldbaum (1946) and Walker, Fisher, and McHugh (1948) subsequently applied the principle to medical problems. Born (1949) in London, and Lous (1950) in Copenhagen, developed similar methods. All these methods depend on the fact that both the position and height of the absorption maximum shown by barbiturate is $\mathrm{a}_{\circ}^{\infty}$ function of $p \mathrm{H}$, and also that most barbiturates? show negligible absorption at wavelengths greater $\vec{T}$ than $235 \mathrm{~m} \mu$ for $p \mathrm{H}$ values below 6.0.

The technique which we have employed is based? on published methods, and aims to combine a reasonable degree of accuracy with a minimum of procedure. By its use it is possible to estimate the c barbiturate content of four samples of blood or $\omega$ urine in about two hours.

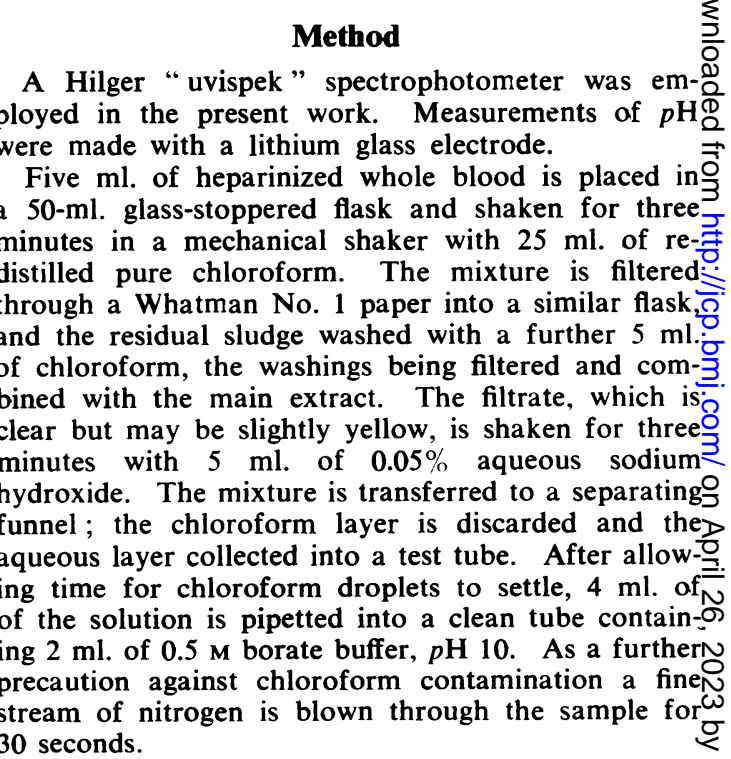

The absorption curve of the sample is obtained over the range 220 to $300 \mathrm{~m} \mu$ against a blank consisting of $4 \mathrm{ml}$. of $0.05 \%$ sodium hydroxide and + $2 \mathrm{ml}$. of borate buffer. A $10-\mathrm{mm}$. cell is usually suit- 0 able, and particular attention is paid to the range 2350 to $245 \mathrm{~m} \mu$. The test and blank solutions are then returned to their respective test tubes and $0.5 \mathrm{ml}$. of concentrated hydrochloric acid added to each. After mixing, the absorption curve is again obtained overe the same wavelength range. 
The extraction procedure for urine, cerebrospinal fluid, and gastric contents is similar to that for blood except that the specimens are adjusted to approximately $p \mathrm{H} 6$ before extraction, and the separation of the two phases after the initial chloroform extraction is performed by the use of a separating funnel, with subsequent filtration of the extract. For the estimation of barbiturates in tissues we have used 1 to $2 \mathrm{~g}$. of wet sample homogenized with $10 \mathrm{ml}$. of phosphate buffer, $p \mathrm{H} 6$, in a large glass homogenizer. The total volume is made up to $15 \mathrm{ml}$. and a $5-\mathrm{ml}$. aliquot extracted in the usual way. Troublesome emulsions frequently occur; we have not been able fully to overcome this difficulty by the use of other solvents as suggested by Goldbaum (1948).

Calculation.-This is made after Walker, Fisher, and McHugh (1948).

The barbiturate concentration in $\mu \mathrm{g}$. per $\mathrm{ml}$. of the final extract (i.e., of the solution as measured in the spectrophotometer cell) is given by the expression

$$
\frac{M \times\left(E_{\text {alk }}-E_{a c}\right) \times 1000}{\varepsilon_{\max }}
$$

where $\mathbf{M}=$ molecular weight of barbiturate; $E_{a l k}=$ optical density in alkaline solution at $239 \mathrm{~m} \mu$ and 10-mm. depth $; \mathrm{E}_{\mathrm{ac}}=$ optical density in acid solution after correction for dilution due to addition of acid ; $\bar{\varepsilon}_{\max }=$ molecular extinction of the barbiturate at $239 \mathrm{~m} \mu$. The barbiturate concentration in the original specimen may readily be calculated from this value.

The values for $M$ and $\varepsilon_{\max }$ in the above expression clearly depend upon the particular barbiturate present. Where the actual compound is unknown we prefer to calculate its concentration provisionally in terms of barbital; since this substance has a low molecular weight and a high molecular extinction a conservative estimate is thereby obtained. In the special case of phenobarbitone a correction is necessary, since this derivative has an abnormally high absorption in acid solution.

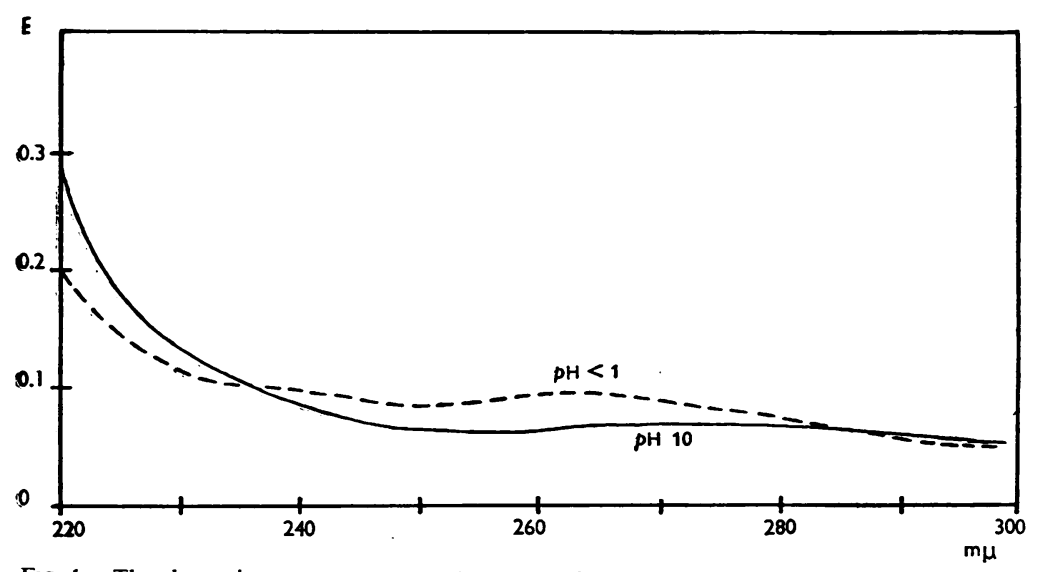

FIG. 1.-The absorption curves represent the means of 10 samples of normal blood. The full line is the absorption in alkaline solution; the dotted line that in acid solution.

\section{Results}

Fig. 1 represents the absorption spectra in alkaline and acid conditions of $5 \mathrm{ml}$. samples of blood from 10 normal subjects. In the absence of barbiturate it is seen that the absorption is practically the same in both acid and alkali at $239 \mathrm{~m} \mu$. (This wavelength is the normal position of the barbiturate peak.)

These blood samples were used to determine the percentage recovery of varying concentrations of barbital added to $5 \mathrm{ml}$. samples. Over a concentration range of 100 to $250 \mu \mathrm{g}$. per $5 \mathrm{ml}$. ( 2 to 5 mg. per $100 \mathrm{ml}$.) the mean recovery in 17 estimations was $60 \%$ with a standard error of the mean of \pm 1 . With concentrations below $100 \mu \mathrm{g}$. per $5 \mathrm{ml}$. it was not always possible to determine the precise amount of barbital because an absorption peak at $239 \mathrm{~m} \mu$ was not always observed owing to the relative preponderance of other chromogens. However, with experience of the method it is possible to make a fair estimate of barbiturate down to levels of $50 \mu \mathrm{g}$. per $5 \mathrm{ml}$. At concentrations above $250 \mu \mathrm{g}$. per $5 \mathrm{ml}$. a lower recovery was obtained; thus the recovery is $55 \%$ at $600 \mu \mathrm{g}$. per $5 \mathrm{ml}$, and about $50 \%$ with concentrations of $1,000 \mu \mathrm{g}$. per $5 \mathrm{ml}$. (20 mg. per $100 \mathrm{ml}$.).

Since $60 \%$ is the recovery obtained over the range found in cases of intoxication, we have felt justified in correcting the final figure for this recovery (i.e., the experimental value is multiplied by 1.67). Using this correction factor, significant over-estimation of the blood level of barbiturate is unlikely. Recovery experiments have not been made on other compounds because it would appear from the work of Walker, Fisher, and McHugh (1948) that no significant variations exist. Urine and gastric contents are so variable in composition that we prefer to give the uncorrected estimate of barbiturate content.

\section{Clinical Data}

Full details of the clinical investigation will be published elsewhere. A brief summary has been made here for correlation with the laboratory findings.

Table I shows some of the data relating to 17 cases of poisoning so far investigated. Previous authors have commented on the lack of any 
TABLE I

SUMMARY OF CLINICAL AND LABORATORY FINDINGS IN 17 CASES OF BARBITURATE INTOXICATION

\begin{tabular}{|c|c|c|c|c|c|c|c|c|c|c|}
\hline Case & Sex & Age & Drug & Dose & 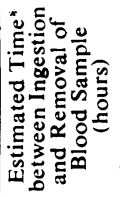 & 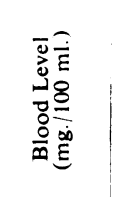 & $\begin{array}{c}\text { Clinical State } \\
\text { when Blood } \\
\text { Sample Taken }\end{array}$ & $\begin{array}{c}\text { Time Taken } \\
\text { for Recovery } \\
\text { or Death }\end{array}$ & $\begin{array}{c}\text { Barbiturate } \\
\text { in Gastric } \\
\text { Washings } \\
\text { (mg.) }\end{array}$ & $\begin{array}{l}\text { Barbiturate } \\
\text { in Urine }{ }^{\dagger}\end{array}$ \\
\hline 1 & $M$ & 46 & Phenobarbitone & Unknown & & & Found dead & & 970 & Bladder urine \\
\hline 2 & M & 45 & Phenobarbitone & Unknown & 24 & $12 \cdot 3$ & Very deep & 4 days & & $322 \mathrm{mg}$. in 5 \\
\hline 3 & $F$ & 80 & Phenobarbitone & Unknown & 24 & $11 \cdot 6$ & $\begin{array}{l}\text { Very deep } \\
\text { coma }\end{array}$ & $\begin{array}{l}\text { Died on } \\
\text { 11th day }\end{array}$ & & $\begin{array}{l}\text { days } \\
65 \mathrm{mg} \text { between } \\
3 \mathrm{rd}-5 \text { th days }\end{array}$ \\
\hline 4 & $\mathbf{M}$ & 64 & Phenobarbitone & Unknown & 20 & $9 \cdot 0$ & Moderately & Died on & 97 & $97 \mathrm{mg}$. \\
\hline 5 & $\mathbf{F}$ & 40 & $\begin{array}{l}\text { Phenobarbitone } \\
+ \text { " amytal }\end{array}$ & $\underset{585 \mathrm{mg} .}{780 \mathrm{mg} .}+$ & 6 & $4 \cdot 1$ & $\begin{array}{c}\text { Moderately } \\
\text { deep coma }\end{array}$ & $24 \mathrm{hr}$. & & $\begin{array}{l}4.8 \mathrm{mg} .100 \mathrm{ml} \text {. } \\
\text { in first speci- }\end{array}$ \\
\hline 6 & $\mathrm{~F}$ & 43 & Phenobarbitone & 585 to 1,170 & 4 & $3 \cdot 5$ & Stuporose & $12 \mathrm{hr}$. & & \\
\hline 7 & $\mathrm{~F}$ & 19 & Phenobarbitone & Unknown & $2-3$ & $2 \cdot 8$ & Very stupo- & $24 \mathrm{hr}$. & 130 & \\
\hline 8 & F & 46 & Phenobarbitone & $1,230 \mathrm{mg}$. & 24 & $2 \cdot 3$ & $\begin{array}{l}\text { Drowsy, ny- } \\
\text { stagmus, } \\
\text { diplopia }\end{array}$ & $24 \mathrm{hr}$. & 130 & \\
\hline 9 & $F$ & 31 & Phenobarbitone & Unknown & 12 & Less than & $\begin{array}{l}\text { No symp- } \\
\text { toms }\end{array}$ & & 355 & \\
\hline 10 & $\mathbf{M}$ & 72 & Barbital & Unknown & & & Found dead & & 195 & $\begin{array}{l}9.2 \mathrm{mg} . / 100 \mathrm{ml} . \\
\text { in bladder }\end{array}$ \\
\hline 11 & $\mathbf{M}$ & 69 & $\underset{\text { ? hashish }}{\text { Barbital }}+$ & Unknown & $\begin{array}{l}\text { Less than } \\
24\end{array}$ & $10 \cdot 7$ & $\begin{array}{l}\text { Very stupo- } \\
\text { rose }\end{array}$ & 2 days & & $\begin{array}{c}\text { urine } \\
900 \text { mg. in } 5 \\
\text { days }\end{array}$ \\
\hline 12 & $\mathbf{M}$ & 51 & Sodium barbital & Unknown & $\begin{array}{l}\text { Less than } \\
24\end{array}$ & $7 \cdot 0$ & Very drowsy & 1-2 days & & $1 \cdot 3 \mathrm{~g}$ in 8 days \\
\hline 13 & $\mathrm{~F}$ & 45 & Butobarbitone & Unknown & $\underset{36}{\text { During }}$ & & Very drowsy & 1 day & 26 & $130 \mathrm{mg}$ in 2 \\
\hline 14 & $\mathrm{~F}$ & 70 & Butobarbitone & Unknown & $\begin{array}{l}\text { Less than } \\
12\end{array}$ & $\begin{array}{c}\text { Less than } \\
3 \cdot 7\end{array}$ & $\begin{array}{l}\text { Moderately } \\
\text { deep coma }\end{array}$ & 1 day & & $\begin{array}{l}65 \mathrm{mg} \text {. in } 14 \\
\mathrm{hr} \text {. }\end{array}$ \\
\hline 15 & $\mathbf{M}$ & 30 & $\begin{array}{c}\text { Pentobarbitone } \\
+\quad \text { alcohol } \\
++\end{array}$ & Unknown & $\begin{array}{l}\text { Less than } \\
12\end{array}$ & $3 \cdot 4$ & Found dead & & 26 & $\begin{array}{r}\text { Less than } 4 \cdot 7 \\
\text { mg } 100 \mathrm{ml} \text { in } \\
\text { bladder urine }\end{array}$ \\
\hline 16 & F & 51 & "Amytal",+ & $\begin{array}{l}450 \mathrm{mg} . \\
290 \mathrm{mg} .\end{array}$ & $4-6$ & $\begin{array}{c}\text { Less than } \\
3 \cdot 2\end{array}$ & Deep coma & $18 \mathrm{hr}$. & $10 \mathrm{mg} / 100$ & $\begin{array}{l}195 \mathrm{mg} \text {. in } 2 \mathrm{l} \\
\text { days }\end{array}$ \\
\hline 17 & $\mathbf{M}$ & 25 & "Amytal" & Unknown & $2-3$ & $1 \cdot 0$ & $\underset{\text { coma }}{\text { Very light }}$ & $12 \mathrm{hr}$. & $\begin{array}{l}\text { Innno } \\
600\end{array}$ & Traces \\
\hline
\end{tabular}

* The time of taking the first blood sample does not necessarily correspond with the time at which gastric lavage was performed.

$\dagger$ The gastric content and urine levels are minimum values.

close correlation between blood level and clinical condition, and particular stress has been laid on the fact that epileptic and other barbiturate habitués may regain consciousness while their blood levels are still high. In Table I, Case 8 was a known epileptic, Case 4 may have been, and Cases 12 and 16 were known to be habituated. Nevertheless, from Table I it would appear that, for a given barbiturate, a correlation between blood level and clinical state does exist when all factors are taken into account. The time given for full recovery is very approximate, and signifies full return to consciousness rather than cessation of vertigo and diplopia, since these symptoms invariably last for several days after severe intoxication. Alcohol ingestion was only presumptive in three cases, but if indeed present it has a significant bearing on the prognosis. The relatively weak hypnotic action of barbitone is evident from the high blood levels compatible with consciousness; on the other hand, it appears that patients suffering from intoxication $\frac{3}{3}$. by rapidly acting barbiturates may be dangerously 0 depressed even with blood barbiturate levels at $₹$ the lower limit of reliable estimation. Barbital is 음 freely excreted, and the urine output and blood $D$ level show an excellent correlation. A relatively good correlation is found with the rapidly acting $\bar{N}$ barbiturates. In our limited experience phenobarbitone is poorly excreted, and high blood levels $N$ may occur with a relatively low urine output.

In two cases, 4 and 11 , there was no circumstantial evidence of ingestion of barbiturate. $\operatorname{In}_{0}$ these cases crystals were obtained from chloro- $\frac{\complement}{\Phi}$ form extracts of urine; the crystals gave no $\stackrel{\mathcal{P}}{+}$ depression of melting point with pure samples of 0 phenobarbitone and barbitone respectively. As 0 additional confirmation the absorption curves of $\stackrel{\odot}{\Phi}$ equal weights of the urine crystals and the known $\stackrel{\mathbb{Q}}{\mathscr{Q}}$ compounds compared very favourably (Figs. $2 \frac{0}{0}$ and 3). 


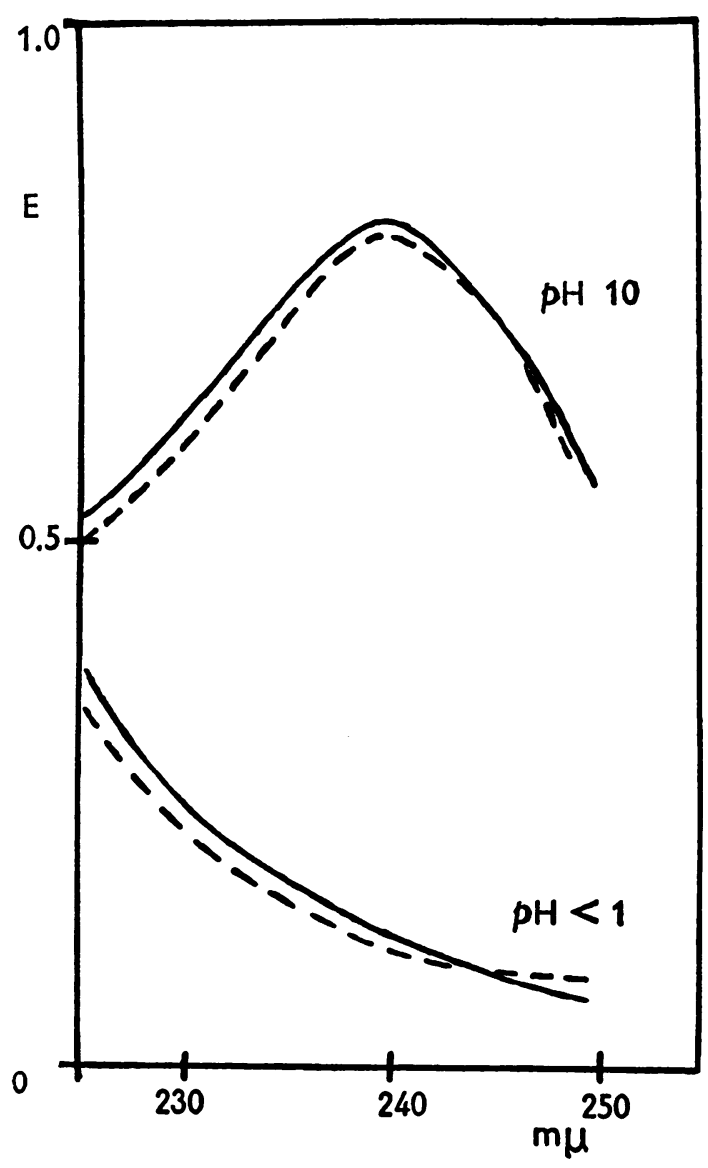

Fig. 2.-Curves illustrating the absorption of crystals isolated from urine of Case 4 compared with pure phenobarbitone. The full lines relate to the crystals dissolved in borate buffer: the dotted lines to the same concentration of phenobarbitone. Note abnormally high absorption of phenobarbitone in acid solution.

Post-mortem material was obtained from Cases 3 and 4 , these patients dying in hospital. Table II indicates the minimum barbiturate concentrations in some tissues examined by our method, and Fig. 4 illustrates the spectra obtained with extracts of blood and liver from Case 4.

Where interfering chromogens are present in high concentration, particularly with urine extracts,

TABLE II

BARBITURATE LEVELS IN POST-MORTEM MATERIAL

\begin{tabular}{|c|c|c|c|c|c|}
\hline & $\begin{array}{l}\text { P.M. } \\
\text { Blood* } \\
\text { (mg./ } \\
100 \mathrm{ml} .)\end{array}$ & $\begin{array}{l}\text { Liver } \\
\text { (mg./ } \\
100 \mathrm{~g} .)\end{array}$ & $\begin{array}{c}\text { Kidney } \\
(\mathrm{mg} . / \\
100 \mathrm{~g} .)\end{array}$ & \begin{tabular}{|} 
Suprarena! \\
Gland \\
(mg.! \\
100 g.)
\end{tabular} & $\begin{array}{c}\text { Spleen } \\
\text { (mg.' } \\
100 \mathrm{~g} .)\end{array}$ \\
\hline $\begin{array}{c}\text { Case } 3 \ldots \\
, \quad 4 \ldots\end{array}$ & $\begin{array}{l}3 \cdot 3 \\
7 \cdot 0\end{array}$ & $\begin{array}{l}3 \cdot 5 \\
9 \cdot 2\end{array}$ & $2 \cdot 8$ & $2 \cdot 6$ & $2 \cdot 1$ \\
\hline
\end{tabular}

* The blood level is corrected on the basis of $60 \%$ recovery; other values are uncorrected and are therefore minimum levels.

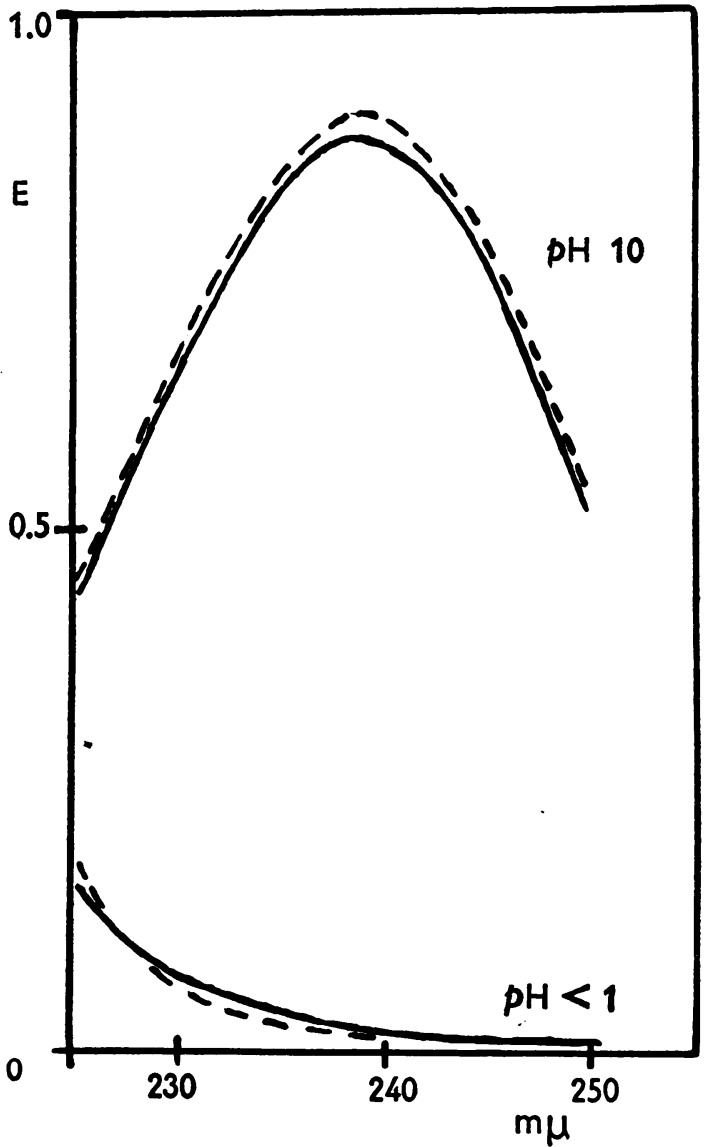

FIG. 3.-Curves illustrating the absorption of crystals isolated from urine of Case 11 compared with pure barbitone. The full lines relate to the crystals dissolved in borate buffer; the dotted lines to the same concentration of barbitone.

no peak may be found in the absorption curve, or a peak may be apparent at a wavelength lower than the $239 \mathrm{~m} \mu$, which is usually the case with barbiturates. A relatively low absorption in acid solution may be suggestive of the presence of barbiturate, but even if there is definite evidence of the ingestion of barbiturate no reliable estimate of amount can be made, although a maximum value may be surmised. In the absence of a peak at $239 \mathrm{~m} \mu$ the presence of barbiturate cannot be inferred without risk, for at least one common group of substances (phenol derivatives) absorbs radiation in alkaline solution but not in acid solution at this wavelength.

In Case 17 the presence of a preponderance of interfering substances in a urine extract can be inferred from the shift of the barbiturate peak to $235 \mathrm{~m} \mu$ and from the high absorption in acid solution (Fig. 5). Amytal crystals were obtained 


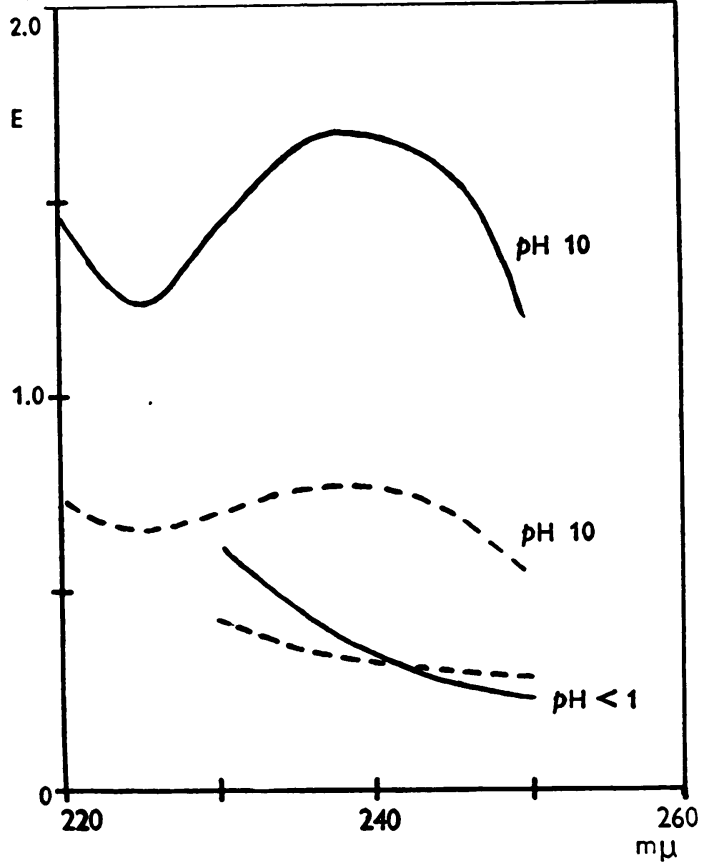

Fig. 4.-Curves illustrating the absorption of extracts of post-mortem blood and liver from Case 4 . The full lines relate to the extract from $5 \mathrm{ml}$. blood; the dotted lines to the extract from $0.7 \mathrm{~g}$. liver (wet weight).

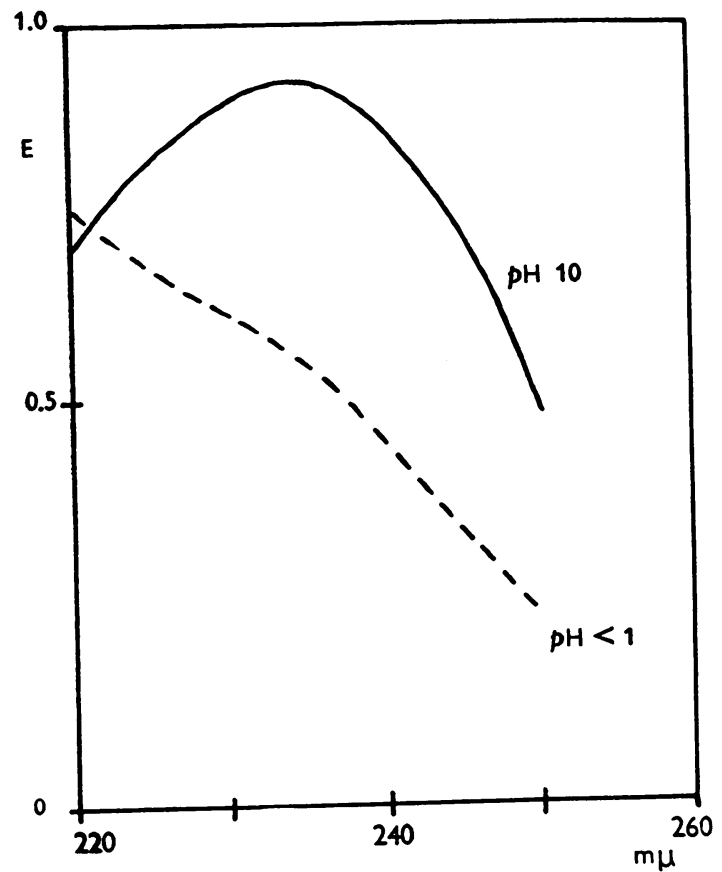

FIG 5.-Curves illustrating the absorption of extract of first 24-hour specimen of urine from Case 17. Note abnormal peak at $235 \mathrm{~m} \mu$ and abnormally high absorption in acid indicative of a high concentration of interfering matter. from chloroform extracts of this urine in sufficient quantity to allow a macroscopic melting point determination to be made. A solution of these crystals showed the normal peak at $239 \mathrm{~m} \mu$.

\section{Discussion}

The method described above is similar to that developed by Lous (1950), which is in turn based on both the procedures of Goldbaum (1948) and Walker et al. (1948). We, however, use whole blood rather than serum, and in this respect, if heparin is the particoagulant, it is essential to use the pure product. Heparin as supplied for intramuscular use contains phenolic preservatives which absorb in alkaline solution over the critical range (Giotti and Maynert, 1951). Oxalate and fluoride do not appear in the final extracts and may be used in place of heparin. In the method described by Lous barbiturate is removed from the chloroform extract by direct shaking with buffer; we have used weak alkali, as there is some evidence that this is more efficient. The $p H$ is subsequently $\vec{v}$ brought to a value of 10 by the addition of buffer. On Lous did not define the lower limit of sensitivity of his technique, and it is impossible to assess his recovery rate as he estimates unknown blood levels by comparison with calibration curves based on the extraction of known amounts of barbiturates $\frac{\mathscr{Q}}{\mathbb{Q}}$ added to normal serum.

In Nilsson's (1951) series Lous determined the $\overrightarrow{\overrightarrow{0}}$ blood barbiturate levels of 58 cases. Unfortunately 3 most of the patients were poisoned by ally-层 propymal (alurate), a drug of which we have no experience, but four cases of phenobarbitone poisoning are described. The most severely:affected was a man of 58 with an initial blood level 3 . of $17.1 \mathrm{mg}$. per $100 \mathrm{ml}$. who died after eight days from anuria and hyperpyrexia. The three other cases were men between the ages of 31 and 52 whoo recovered after initial blood levels of $15.5 \mathrm{mg}$. per $100 \mathrm{ml}$. (deep coma); $9.9 \mathrm{mg}$. per $100 \mathrm{ml}$. (deep coma, epileptic); and $5.3 \mathrm{mg}$. per $100 \mathrm{ml}$. (light coma).

The method described by Walker, Fisher, andr McHugh (1948) has theoretical advantages, but, N despite the elaborate steps taken to procure a relatively chromogen-free alkaline solution for $₹$ spectroscopy, their normal blood extracts appear? to absorb nearly as much radiation as ours and? their recovery rate is only $70 \%$. They claim a sensitivity of $0.4 \mathrm{mg}$. per $100 \mathrm{ml}$. of blood, and $\overline{0}$ using this technique, Fisher, Walker, and Plummer (1948) found two cases of coma following ingestion? of seconal and phenobarbital with blood levels as low as 1.0 and $0.8 \mathrm{mg}$. per $100 \mathrm{ml}$. respectively? 
In two fatal cases blood pentobarbital levels of 0.6 and $0.7 \mathrm{mg}$. per $100 \mathrm{ml}$. were found, but both patients were chronic alcoholics. Walker, Fisher, and McHugh discuss in some detail the identification of other drugs, notably salicylates and sulphonamides, which may interfere with the spectrophotometric estimation of barbiturate, and they mention the advisability of scanning the whole range between 220 and $300 \mathrm{~m} \mu$. They also state that picrotoxin, benzedrine, and caffeine do not interfere. This has also been our experience, but it is possible that xanthine derivatives contribute to the high levels of chromogens in urinary extracts.

Goldbaum (1948) also claimed a sensitivity of $0.4 \mathrm{mg}$. per $100 \mathrm{ml}$. of blood. He summarizes barbiturate analyses on seven fatal and three nonfatal cases. It is of some interest that in two fatal cases poisoned by seconal and pentobarbital respectively he found a concentration of barbiturate in the liver five times that in the blood. Born (1949) uses an ethanol-ether-alkali extraction technique ; he mentions that the method is suitable for blood, but gives no clinical data. Giotti and Maynert (1951) used an ether extraction method for studying the renal clearance of barbital in dogs. By treating their ether extracts of blood and urine with activated charcoal they achieved considerable reduction in interfering chromogens without significant loss of barbital. It is doubtful whether this refinement can be applied in the case of all barbiturates, particularly where chloroform is the solvent.

\section{Summary}

A modification of existing methods for the ultra-violet spectrophotometric estimation of bar- biturates in biological fluids and tissues is described.

Seventeen cases of barbiturate intoxication are recorded; blood and urine barbiturate levels appear to be related to the degree of depression of the nervous system.

Blood barbital levels up to $10 \mathrm{mg}$. per $100 \mathrm{ml}$. and phenobarbitone levels up to $5 \mathrm{mg}$. per $100 \mathrm{ml}$. may be compatible with consciousness, whereas coma is usually produced with levels of shortacting barbiturates of only 1 to $2 \mathrm{mg}$. per $100 \mathrm{ml}$. Alcoholic intoxication may be a complicating factor.

Urinary clearance is low for phenobarbitone, good for quick-acting barbiturates, and high for barbital.

We wish to express our gratitude to Professor Clifford Wilson for encouragement and criticism, to Dr. and Mrs. Morris and Drs. Holiday and Beavan for advice, to the physicians of the London Hospital. Dr. Alastair Hunter of St. George's Hospital, and Dr. F. E. Camps for allowing us to take specimens, to Professor J. R. Marrack for making available the Hilger " uvispek" spectrophotometer, and to Mr. C. H. Sykes, chief pharmacist at the London Hospital, for his constant co-operation.

\section{REFERENCES}

Born, G. V. R. (1949). Biochem. J., 44, 501

Elvidge, W. F. (1940). Quart. J. Pharm., 13, 219.

Fisher. R. S., Walker, J. T., and Plummer, C. W. (1948). Amer. J. clin. Path., 18, 462.

Giotti, A., and Maynert, E. W. (1951). J. Pharmacol., 101, 296.

Goldbaum, L. R. (1948). Ibid., 94, 68.

Jailer, J. W., and Goldbaum, L. R. (1946). J. Lab. clin. Med., 31, 1344.

Lous, P. (1950). Acta pharmacol., Kbh., 6, 227.

Nilsson, E. (1951). Acta med. scand., Suppl. 253.

Riley, R. F., Krause, R. F., Steadman, L. T., Hunter, F. E., and Hodge, H. C. (1940). Proc. Soc. exp. Biol., N.Y., 45, 424

Stuckey, R. E. (1940). Quart. J. Pharm., 13, 312; (1941), 14, 721 ; (1942), 15, 370, 377 .

Walker, J. T., Fisher, R. S., and McHugh, J. J. (1948). Amer. J. clin. Path., 18, 451 . 